\section{Creating the Urban Eden: Sustainable Landscape Establishment in Theory and Practice}

\author{
Nina Bassuk ${ }^{1,3}$ and Peter Trowbridge ${ }^{2}$
}

AdDITIONAL INDEX WORDS. woody plant selection, site assessment, soil remediation, teaching collaboration

Summary. Creating the Urban Eden, a course taught jointly by faculty in Landscape Architecture and Horticulture at Cornell University, is a unique two-semester class spanning the academic year from August to May. Students face the task of creating viable, sustainable landscapes both in theory and practice. The success and sustainability of any planting design is ultimately dependent upon knowledgeable site assessment and analysis, appropriate plant selection, and clear communication of design intentions. This class teaches all aspects of landscape establishment, including detailed site assessment, woody plant identification, choice of appropriate plants, planting design, soil remediation, transplanting, and early maintenance in human-impacted landscapes. In addition to designing for a specific site, students learn about written specifications for technical planting and graphic details to communicate and implement design proposals. Every year on the Cornell University campus, the students in this class implement, in a hands-on manner, all aspects of landscape establishment that they have learned by creating new landscapes that serve to integrate theory, principles, practice, and provide a demonstration of fundamentals taught in the class.

$\mathrm{I}$ n 2000, two Cornell University faculty members from the Department of Horticulture and Department of Landscape Architecture joined together to develop a course that teaches the principles, processes, and practical techniques of landscape establishment combined with a thorough knowledge of woody plant identification and their use in the landscape. The student audience, primarily graduate and undergraduate students in landscape architecture, also includes students in horticulture and related fields. A typical class numbers 40 students. Much of the information presented is derived from research carried out by the Urban Horticulture Institute in the Department of Horticulture at Cornell University, a program that focuses on the rehabilitation of difficult urban or human-impacted sites.

\section{Premises}

The course is based on the premise that you cannot design and establish a new landscape until you have a thorough knowledge of site conditions. A comprehensive site assessment drives

\footnotetext{
${ }^{1}$ Professor, Department of Horticulture, Cornell University, 134A Plant Science, Ithaca, NY 14853

${ }^{2}$ Professor, Department of Landscape Architecture, Cornell University, Kennedy Hall, Room 440, Ithaca, NY 14853

${ }^{3}$ Corresponding author. E-mail: nlb2@cornell.edu.
}

design and the choice of plant material. A broad knowledge of plant environmental stress tolerance and pest resistance, as well as design and management considerations is the basis for long-term success of the landscape. Moreover, when site conditions are found to be so difficult that the choice of appropriate plants is severely limited, site remediation must occur before landscape development can be successful. Only when armed with this information can appropriate plants be chosen, installed, and managed in a new landscape.

Long before the term "sustainability" became commonplace, the idea of teaching environmentally sound landscape design and establishment was the underlying premise of this course. The use of non-invasive, siteappropriate plants and the rehabilitation of the soil are key features that figured into these practices. As the term sustainable has become more frequently used, its definition has gained greater clarity. In 1987, the United Nations Brundtland Commission report stated "Sustainable development is development that meets the need of the present without compromising the ability of future generations to meet their needs" (United Nations World Commission on Environment and Development, 1987). When applied to the landscape, we can say that sustainable landscapes are those that create or preserve the functional ecosystem services necessary for today without reducing those services for future generations.

Healthy landscapes provide a wide diversity of ecosystem services that have been increasingly recognized and quantified (deGroot et al., 2002). A sustainable landscape helps to regulate climate and energy use by mitigating the effects of sun and wind, reducing pollutants, and taking up carbon dioxide. Such landscapes also reduce storm water and flooding through plant water uptake and water infiltration, recharge, and evaporation in soils. Healthy soils filter polluted water. Landscapes provide habitat for pollinators and a host of other organisms, including humans. Landscapes are important for human health and well being. These services and many others can only be achieved when landscapes are designed in such a way that they ensure the health of the plants and soil without relying on the overuse of resources such as water and fossil fuels during their maintenance.

The idea that sustainable landscapes provide necessary ecosystem services has more recently been embraced by the Sustainable Sites Initiative (SSI), an interdisciplinary partnership, led by the American Society of Landscape Architects, the Lady Bird Johnson Wildflower Center, and the U.S. Botanic Garden to develop voluntary guidelines aimed at fostering landscapes that provide ecosystem services through appropriate design, implementation, and management practices (SSI, 2008). This is a national effort engaging multiple stakeholders on subcommittees focusing on vegetation, soils, hydrology, materials, and human health and well being. The SSI guidelines and rating system is still a work in progress that should be operational by 2012. However, students must have familiarity and knowledge to be ready to implement sustainable design strategies and maintenance practices if they are to be leaders in their professional roles as these practices become more and more accepted.

Although sustainable landscape practices are highly desirable, Creating the Urban Eden helps students design and establish landscapes without prescribing one type of design ideal. Sustainable design may use any design aesthetic as long as the processes of 
site assessment, appropriate plant selection, soil amelioration, and sound installation and management are followed. The objectives are 1) to gain a firsthand understanding of the heterogeneity of urban and other growing conditions and to know how these various conditions might influence plant selection, growth development, and survival; 2) to learn the site assessment techniques and analytical skills necessary to diagnose various site conditions and to determine how to use this information in planting design; 3 ) to learn about plant massing, spacing, and growth habits by mapping recently installed landscapes; 4) to develop observation techniques, practice nomenclature, and recognize plant characteristics necessary for their identification; 5 ) to select site-appropriate plant materials and to demonstrate technically how to develop construction documents for contractor bidding and installation; 6) to develop a working knowledge of soil modification techniques and to know when it is appropriate to use them; 7) to learn new and innovative pruning, maintenance, and transplanting techniques and have an opportunity for handson practice, and to develop a maintenance plan; and 8) to put theory into practice on a real site on the Cornell University campus.

\section{Strategies}

To accomplish these objectives, the course is a two-semester sequence where, in the fall semester, students initially learn how to assess a site on campus that will eventually be designed and built while learning about the identification and use of over 200 woody plants. Assessment in this context is defined as understanding the limitations and opportunities for plant growth and design realization inherent in the site. In the spring semester, students learn about soil remediation, innovative detailing (the graphic representation of how things are built), and the identification and use of another 150 woody plants. During the month of April, the students remediate the soil, prepare the site, and install new landscape for a selected on-campus site. By teaching plant materials and landscape establishment in an integrated, hands-on manner, students learn the interconnectedness of practices necessary for successful landscape design and landscape realization. This curriculum is not without its challenges. The variability of weather and the ability to transport bulky materials to a design site at the heart of the Cornell University campus can create moments of difficult coordination. In addition, the selection of a highly visible campus site has benefits relative to landscape enhancement, but also is exposed to the political considerations of site selection. Also, funding for materials, especially plants, must be negotiated with the college and institution annually.

\section{Implementation}

The syllabus follows the process of site assessment, plant selection, soil remediation, and landscape installation with two, 4-h classes per week. One class per week covers plant identification and use in the landscape and the other class covers a related area of landscape establishment. For instance, in one week, soil physical properties that determine drainage, water holding capacity, and porosity are covered as well as a related set of plants for identification. Students then learn about the tests that measure texture, drainage, aggregate stability, and water holding capacity. They then go to the design site on campus and practice those tests. During the next class, students learn to identify and use approximately 25 woody plants that relate to the campus design site. Of the over 350 plants covered, many are taught in categories by landscape use, such as wettolerant plants or groundcovers or high $\mathrm{pH}$-tolerant plants, while others are taught by taxonomic groupings such as maple (Acer spp.), oak (Quercus spp.), or viburnum (Viburnum spp.). Regardless of how they are grouped, students learn about identification features, environmental and biotic stress tolerance, cultivar variations, ornamental properties, and management concerns for each plant.

Because students learn information differently, we provide many different ways of learning about the plants we cover each week such as using live samples, herbarium samples, printed identification handouts, a searchable woody plant website, (Bassuk, 2009), and walks to see the plants on the Cornell University campus throughout the year. The long, 4-h class period allows for a combination of learning methods, including lectures, hands-on plant exploration, site assessment tests, soil remediation testing, and field trips. Typically, students will do a short design exercise with the plants they have learned that week. Students also learn how to specify plants using a planting key and use appropriate plant production types and sizes to achieve their design intent. One of the most difficult things to teach new designers is about plant spacing and numbers. After several years of trial and error, we have found that having the students draw a fairly recently planted landscape on a base map gives them a good idea of how many plants it takes to create a particular effect. By using a recent planting, students can see how many plants it takes to create the effect they see.

Although Creating the Urban Eden originated before the current interest in sustainability, it falls directly in line with the principles of creating landscapes that foster ecosystem services.

By creating a thriving, healthy landscape with plants and soils well adapted to the site, students not only learn the principles of assessment, mitigation and design, but they also build the landscape. There is a more enduring learning process that takes place through the combination of theory and implementation. In exit interview surveys at graduation, students expressed confidence in their ability to design site-sensitive, sustainable projects after taking this course. Moreover, students can implement their design skills and see that there are many ways to achieve a sustainable landscape.

\section{Literature cited}

Bassuk, N.L. 2009. Cornell University woody plants database. 6 July 2009. <http://urie.mannlib.cornell.edu/ woody_plants/index.php $>$.

de Groot, R.S., M.A. Wilson, and R.M. Boumans. 2002. A typology for the classification, description and valuation of ecosystem functions, goods and services. Ecol. Econ. 41:393-408.

Sustainable Sites Initiative. 2008. The Sustainable Sites Initiative guidelines and performance benchmarks: Draft 2008. 6 July 2009. <http://www.sustainablesites. org/report $>$.

United Nations World Commission on Environment and Development. 1987. Our common future. Oxford University Press, Oxford, UK. 